\title{
Effectiveness of Proactive Intensive FFI in Cultivating Grammatical Knowledge of Iranian EFL Learners at Different Proficiency Levels
}

\author{
Amir Rooholamin ${ }^{1}$, Reza Biria ${ }^{1} \&$ Hamid Reza Haghverdi ${ }^{1}$ \\ ${ }^{1}$ Department of English, Isfahan (Khorasgan) Branch, Islamic Azad University, Isfahan, Iran \\ Correspondence: Amir Rooholamin, Department of English, Isfahan (Khorasgan) Branch, Islamic Azad \\ University, Isfahan, Iran. Tel: 98-913-319-3001. E-mail: Rouholamin@yahoo.com
}

Received: January 3, 2016

Accepted: February 14, 2016 Online Published: February 16, 2016

doi: 10.5539/elt.v9n3p197

URL: http://dx.doi.org/10.5539/elt.v9n3p197

\begin{abstract}
The present study provides a report on an experiment seeking the effect of proactive intensive form-focused instruction on the grammatical development of intermediate and advanced Iranian EFL learners. More specifically the aim of the study was to discern (a) whether the grammatical knowledge of Iranian EFL learners at different proficiency levels ameliorated in the wake of exposure to proactive intensive FFI (b) whether the grammatical knowledge of the learners at the two proficiency levels improved equally or not, and (c) whether there was an interaction effect between the FFI and the proficiency level, which affected the grammatical development of the learners. To meet these objectives, 119 intermediate and advanced EFL learners at Sadr Institute of Higher Education in Isfahan, Iran were asked to take part in this study. To ascertain the homogeneity of the participants, a QPT was administered to them. The learners in each proficiency level were assigned to a control and an experimental group and they sat for a grammar pretest. Subsequently, the learners in the treatment groups received proactive intensive FFI (metalinguistic explanations followed by repeated form-focused tasks and explicit corrective feedback on form) in their free discussion classes, while those in the control groups participated in classes bereft of FFI. After 9 sessions of instruction, the learners took a posttest. Such statistical tools as paired sample $t$ test and two-way ANOVA were utilized to analyze the collected data, and the following results were obtained: (a) both intermediate and advanced group learners experienced a boost in their grammatical knowledge after being exposed to proactive intensive FFI (b) the treatment in the current study was more beneficial to intermediate EFL learners' grammatical development than it was to advanced learners', and (c) proactive intensive FFI, proficiency level, and the interaction between them all were instrumental in molding the grammatical knowledge of Iranian EFL learners. The implications for EFL practitioners are enumerated in the paper.
\end{abstract}

Keywords: proactive intensive FFI, grammatical knowledge, proficiency level, EFL learners

\section{Introduction}

\subsection{Form-Focused Instruction and Grammatical Development}

A central goal of much research within the realm of second language acquisition has been to develop insight into how grammar develops in the process of second language learning. An understanding of this development is crucial in enabling educators to design instruction that will facilitate language acquisition in second language classrooms. In this study, the development of grammar was explored within the pedagogical framework of form-focused instruction. Form-focused instruction (FFI) is an approach to achieving the integration of content and language by calling attention to language form in meaning-focused language teaching (Spada, 1997). A central axiom underlying FFI is the conviction that attention to language form is essential for language acquisition (Schmidt, 1990). In classroom, FFI is conducted by means of a number of pedagogical alternatives from the very implicit, in which learners are exposed to language form indirectly, to very explicit instruction that involves metalinguistic explanations of grammar. The common feature is that both are meant to integrate form with meaning. Research examining the overall fruitfulness of FFI has generally proved positive and it is widely acknowledged that instruction that connects form and meaning in instructed SLA is more efficient than instruction that exclusively underscores meaning (Doughty \& Williams, 1998; Ellis, 2001; Lyster, 2007; Norris \& Ortega, 2000; Spada, 1997; Swain, 2000). However, findings have been inconclusive and a number of more specific questions germane to FFI have deserved attention. These include: what kinds of FFI are most effective; 
which linguistic forms lend themselves to FFI; and to what extent should focus on form be amalgamated into meaning-focused instruction (Doughty \& Williams, 1998; Ellis, 2001; Norris \& Ortega, 2000; Spada, 1997; Spada \& Lightbown, 2008; Williams, 2005).

Given that grammar, as has been deemed as an inseparable component of any high-stake English language test in the educational context of Iran, has invariably been the forefront of attention in this setting, it obviously calls out for an all-out attempt to seek the most efficacious pedagogical procedures by which success in grammatical accuracy can be achieved. Surprisingly, FFI research in general and FFI studies in adult contexts in Iran in particular, to date, have been insufficient. FFI research has not resulted in defensible, robust, conclusive findings and the results of such studies have at times turned out to be contrary. This is especially true when it comes to the investigation of the effects of different types of FFI on grammatical knowledge of the EFL learners. Moreover, catering the learners at differing levels of proficiency with FFI has almost gone unnoticed in the past literature. Consequently, the question shrouded in mystery is to what extent proactive intensive FFI, as a type of FFI, influences grammatical knowledge of Iranian EFL Learners with different proficiency levels.

\subsection{Relevant Scholarship}

The term focus on form was introduced by Long (1991), who used it to describe instruction that aims to "overtly draw students' attention to linguistic elements as they arise incidentally in lessons whose overriding focus is on meaning" (p. 47). He used this term to contrast it with focus on forms, which refers to approaches in which teaching is organized around a pre-planned syllabus of grammatical forms. For Long, the distinguishing features of focus on form were a primary focus on meaning, and attention to form that was spontaneous, arising during instruction. Other researchers, nonetheless, have since used the term form-focused instruction (Ellis, 2001; Spada, 1997) to describe a broader application of a focus on form. Ellis (2001) applies this term to include attempts to draw attention to form within any teaching approach, involving programs that revolve around linguistic units. Spada (1997) situates FFI within meaning-based instruction and provides a definition appropriate to content-based language instruction: "any pedagogical effort which is used to draw the learners" attention to language form either implicitly or explicitly" and "occurs within meaning-based approaches to L2 instruction" (Spada, 1997, p. 73). In the present study, the term FFI was used to indicate instruction designed to draw attention to form in communicative classrooms. More specifically, the effectiveness of a particular type of FFI, i.e. proactive intensive FFI, in the grammatical development of Iranian EFL learners was subjected to investigation.

The literature on FFI includes terms such as proactive vs. reactive (Doughty \& Williams, 1998); planned vs. incidental (Ellis, 2001); and planned vs. spontaneous (Williams, 2005). A focus on form can be planned and proactive when a teacher identifies and selects, prior to the commencement of instruction, language forms that will be demanding for the learner and/or necessary for the purpose of communicative activities and plans instruction to call attention to these forms. Among the pedagogical options of FFI, one may choose to carry out intensive vs extensive instruction: the former concerns itself centrally with a detailed in-depth treatment of a limited number of linguistic features, while the latter lends itself to a teaching wider array of linguistics items in a more perfunctory fashion. Studies have examined the effectiveness of input manipulation in a range of different contexts with contradictory results. In a study with children in an ESL program, White (1998) compared the effects of typographically enhanced input with a written input flood and found no significant difference between the two treatment groups. Lee (2007) studied the effectiveness of text enhancement in a program with a group of young adults studying English in Korea and found positive effects on language learning outcomes. Leow, Egi, Nuevo, and Tsai (2003) compared the benefits of enhanced and unenhanced text with university students of Spanish and found no benefits for text enhancement. Leeman et al. (1995) carried out a quasi-experimental study investigating input enhancement with adults studying Spanish via content in a university program and the results turned out to be positive when compared with entirely meaning-focused instruction. In the study by Leeman et al. (1995), however, input enhancement comprised typographically enhanced text, corrective feedback as recasts and instructions to learners to focus on form during activities.

Empirical research situated in communicative language classrooms provides some support for an explicit focus on form that includes the provision of metalinguistic explanation. For example, White and Ranta, (2002) compared two treatments with children in an ESL program: one group was provided with meaning-focused instruction only while the other was given a rule of thumb and contrasts between the L1 and L2 were highlighted. The learners were also engaged in tasks designed to elicit discussion about the target form, described as 'consciousness-raising' tasks (see Fotos, 1994; Sharwood-Smith, 1981). In this study, the form-focused group performed better than the meaning-focused group on both an oral production task and a correction task requiring metalinguistic knowledge. In another recent study with adults, Radwan (2005) compared rule-driven instruction 
with text enhancement and content-oriented instruction and found positive results for the rule-driven group.

The provision of grammatical explanation plays a key role in Processing Instruction (PI), a model of instruction designed to help learners focus on form in a meaning-based context by addressing the structural aspects of form before learners are engaged in meaning-focused activities. This is intended to help the learner make form-meaning connections in the input (VanPatten, 1996, 2000). PI is premised on a model of second language acquisition that considers how learners process language so they are able to decode linguistic form from input when their primary attention is on meaning. The model is premised on the assertions that the capacity of working memory is limited, making it difficult for learners to pay attention to form and meaning at the same time, and that learners are driven to focus on meaning before form. In PI, grammatical explanation is used to trigger form-meaning connections in the initial stage of comprehension before moving toward any production of language. Empirical research has supported the benefits of PI when compared with output based approaches (e.g., Benati, 2005; Cadierno, 1995; Qin 2008), although the model has also drawn criticism (Dekeyser, Salaberry, Robinson, \& Harrington, 2002).

Given all the theoretical and empirical studies reviewed above, an urgent need is felt to carry out a study within the framework of FFI which examines the effectiveness of form-focused instruction in the grammatical development of Iranian EFL Learners with different levels of proficiency.

\subsection{Research Questions}

In order to achieve the aforementioned objectives, the following research questions were formulated:

1) Does the grammatical knowledge of Iranian EFL learners at different proficiency levels improve significantly as a result of exposure to proactive intensive FFI?

2) Does proactive intensive FFI affect the grammatical knowledge of Iranian EFL learners at different proficiency levels equally?

3) Do input delivery method (i.e. with or without FFI) and level of proficiency influence Iranian EFL Learners' grammatical knowledge? Will there be an interaction effect for FFI and proficiency level in this regard?

\section{Method}

The research questions of the present study were investigated via a quasi-experimental study that utilized pretest and posttest measures and was conducted over a 4-week period. The study was carried out in a program of general proficiency language instruction for EFL learners at Sadr Institute of Higher Education (SIHE), Isfahan, Iran. One hundred nineteen learners participating in the study attended either of intermediate, or advanced classes. The learners in the experimental groups received proactive intensive form-focused instruction. Grammatical knowledge of the learners was compared on the pretest and posttest to find out if they improved in light of proactive intensive FFI.

\subsection{Participants}

To choose the participants for this study, English learners studying at SIHE who were taking a free discussion course were asked to take part in the study. Altogether, they formed an aggregate of 119 male and female students who were all native speakers of Persian, with an age range of 18 to 34 . The participants had been already placed, based on the SIHE placement criteria. To further assure the homogeneity of the participants in each group, a Quick Placement Test (QPT) was given to them in order to exclude from the analysis those whose language abilities were far below or above the average students in each group. Those selected to serve as the subjects of the study (i.e. a total of 110) constituted four groups: intermediate experimental group (IEG), intermediate control group (ICG), advanced experimental group (AEG), and advanced control group (ACG). Given the fact that the size of a free discussion class normally does not permit a sample of more than 15 , the researcher decided to assign two classes for each of the previously mentioned groups. In so doing, an ample sample size could be achieved for each group.

\subsection{Materials and Instruments}

Prior to developing different instructional packages, the researchers observed several free discussion courses at different institutes, examined textbooks and materials for these courses, and discussed ideas related to the content of the packages with free discussion instructors and their colleagues. After the packages were developed, the researchers and two other Ph.D. holders of TEFL reviewed them. They provided ample feedback for the revision of the instructional materials which were used in this study.

It should also be noted that the selection of the instructional materials was the same for both control and experimental groups at each level of proficiency. The way they were taught, however, was different. That is, 
grammatical structures were presented and practiced based on proactive intensive method of FFI for the two experimental groups. Yet, the same materials were presented to the control groups without following FFI principles. What follows is a description of the different materials utilized for the different groups in this research study.

\subsubsection{Materials}

\subsubsection{Materials for Intermediate Groups}

The instructional materials for the intermediate groups consisted of grammar lessons, including nine different tenses, namely simple present, present continuous, present perfect, simple past, past continuous, past perfect, simple future, future continuous, and future perfect. Each session was allocated to teaching one of the above-mentioned grammar tenses. It should be noted that the topics of the free discussion classes were opted for based on their congruency with the selected grammar tenses. For instance, to teach simple future and simple past, the following topics were picked up respectively: "What are your plans for the future?" and "How did you spend your summer vacations as a child?" The intended materials for teaching verb tenses were extracted form Fundamentals of English Grammar (4 ${ }^{\text {th }}$ ed.) by Azar (2011).

\subsubsection{Materials for the Advanced Groups}

The advanced groups were exposed to materials comprising grammar lessons consisting of the very same nine different verb tenses which were taught to the intermediate groups, though from an advanced grammar book. As was the case with intermediate groups, one of the above-mentioned grammar tenses was taught in each session commensurate with the selected topics of the free discussion classes. Understanding and Using English Grammar ( $4^{\text {th }}$ ed.) by Azar (2009) was exploited for the preparation of grammar lessons for advanced learners.

\subsubsection{Instruments}

In order to homogenize the learners, a QPT was administered. In addition, for the purpose of assessing the effect of proactive intensive FFI on grammatical development of the learners, quantitative data were gathered using grammar pretest and posttest.

\subsubsection{QPT}

The QPT is a placement test for learners of English, produced by the University of Cambridge ESOL Examinations (formerly UCLES). The test takes approximately 30-45 minutes to complete, during which students answer 60 multiple-choice questions. The test is developed based on a bank of hundreds of multiple-choice questions and tests grammar, vocabulary, reading. The QPT has been extensively used as a placement test by a myriad of L2 researchers all over the world, and has been shown to enjoy an acceptable level of reliability (Berthold, 2012).

\subsubsection{Grammar pretest and Posttest}

The intermediate and advanced grammar pretests comprised multiple-choice questions, which measured the grammar knowledge of the learners. Each of these grammar tests consisted of 20 researcher-made items, the reliability and validity of which were determined via KR-21 and content analysis procedures, respectively. It is noteworthy to point out the grammar posttests were constructed out of the same questions as the pretests, though with different item and choice arrangements. The reliability coefficients of the grammar pretests and posttests for the intermediate and advanced learners were $.79, .83, .89$ and .85 , respectively.

\subsection{Data Collection Procedure}

Firstly, a QPT was given to the participants in the first session of the term. Based on the obtained scores, 110 out of 119 intermediate and advanced learners were selected to serve as the participants of the study and were assigned to experimental and control groups. The next session they sat for the pretest, which was meant to assesse their grammatical knowledge. Similarly, the posttest was administered during a separate session after the implementation of the experiment. The instruction took place throughout the sessions between the pretest and the posttest.

During the four-week period of the instructional treatment, the 2 FFI groups followed the same syllabus, though with two differing instructional packages compatible with their proficiency level, focusing on the targeted language, i.e. verb tenses and vocabulary items intended to be taught. The control groups, however, received the input which was not focused by any means. The FFI consisted of (a) metalinguistic explanations, i.e. explicit explanations of the grammar, (b) repeated form-focused tasks, i.e. several tasks used to direct learners' attention to the importance of grammatical knowledge, and (c) explicit corrective feedback on form, where the teacher 
corrected the learners' errors by explicitly stating that they were incorrect and asking learners to explain the error and correct it by referring to grammatical components and terms explicitly.

The control groups, on the other hand, were exposed to (a) no explicit metalinguistic explanations with reference to grammar; language forms were used but never expounded on by the teacher, (b) meaning-focused communicative tasks with no reference to grammar, in which learners were asked to complete tasks by providing the correct content, and (c) implicit corrective feedback via recasts, where the teacher responded primarily to learners' errors in content. During each session, a verb tense was the center of focus. This way, after the placement test and pretest sessions, there were nine instructional sessions, followed by a posttest session, which constituted an aggregate of 12 sessions.

\section{Results}

\subsection{Results for the First Research Question}

The first research question posed in this study investigated whether the grammatical knowledge of Iranian EFL learners at different proficiency levels improved significantly as a result of exposure to proactive intensive FFI. The corresponding null hypothesis would posit that the grammatical knowledge of learners at different levels of proficiency would not improve significantly as a result of exposure to proactive intensive FFI. To test this hypothesis, the pretest and posttest grammar scores of intermediate experimental group (IEG) learners were compared via a paired-samples $t$ test, and the same statistical operation was conducted to compare the pretest and posttest grammar scores of the learners in the advanced experimental group (AEG). The results of these analyses are presented in Tables 1 and 2 .

Table 1. Descriptive statistics results comparing pretest and posttest scores of the IEG and AEG

\begin{tabular}{llllll}
\hline Groups & Tests & $N$ & Mean & Std. Deviation & Std. Error Mean \\
\hline \multirow{2}{*}{ IEG } & Pretest & 29 & 12.10 & 1.98 & .36 \\
& Posttest & 29 & 15.82 & 1.77 & .32 \\
\hline \multirow{2}{*}{ AEG } & Pretest & 28 & 14.35 & 1.66 & .31 \\
& Posttest & 28 & 16.46 & 1.64 & .31 \\
\hline
\end{tabular}

A comparison of the grammar mean scores of the pretest and the posttest reveals that for the two groups, the posttest mean scores surpassed their pretest mean scores. To be more precise, IEG learners could obtain a mean score of 15.82 on the posttest, while their pretest mean score was 12.10. Similarly, for AEG learners, the posttest mean score $(M=16.46)$ was far greater than their pretest mean score $(M=14.35)$. The significance or insignificance of these differences between the pretest and posttest scores of the two groups could be determined in the paired-sample $t$ test table below (Table 2).

Table 2. Paired-Samples $t$ test results comparing pretest and posttest scores of the IEG and AEG

\begin{tabular}{|c|c|c|c|c|c|c|c|}
\hline & \multirow[t]{2}{*}{ Mean } & \multirow{2}{*}{$\begin{array}{c}\text { Std. } \\
\text { Deviation. }\end{array}$} & \multirow[t]{2}{*}{$t$} & \multirow{2}{*}{$d f$} & \multirow{2}{*}{$\begin{array}{c}\text { Sig. } \\
\text { (2-tailed) }\end{array}$} & \multicolumn{2}{|c|}{$\begin{array}{l}\text { 95\% Confidence Interval of the } \\
\text { Difference }\end{array}$} \\
\hline & & & & & & Lower & Upper \\
\hline IEG Pretest-Posttest & -3.72 & .59 & -33.91 & 28 & .000 & -3.94 & -3.49 \\
\hline $\begin{array}{c}\text { AEG } \\
\text { Pretest-Posttest }\end{array}$ & -2.10 & .56 & -19.66 & 27 & .000 & -2.32 & -1.88 \\
\hline
\end{tabular}

Since the Sig. (2-tailed) value represents a $p$ value lower than the significance level $(.000<.05)$ for the IEG, it could be construed that the difference between the pretest and posttest grammar scores of the IEG learners had been statistically significant. The same was also the case with the pretest and posttest grammar scores of the AEG. This means that for both intermediate and advanced group learners, the grammatical knowledge of the learners improved significantly as a result of exposure to proactive intensive FFI. This result is also graphically represented in Figure 1. 


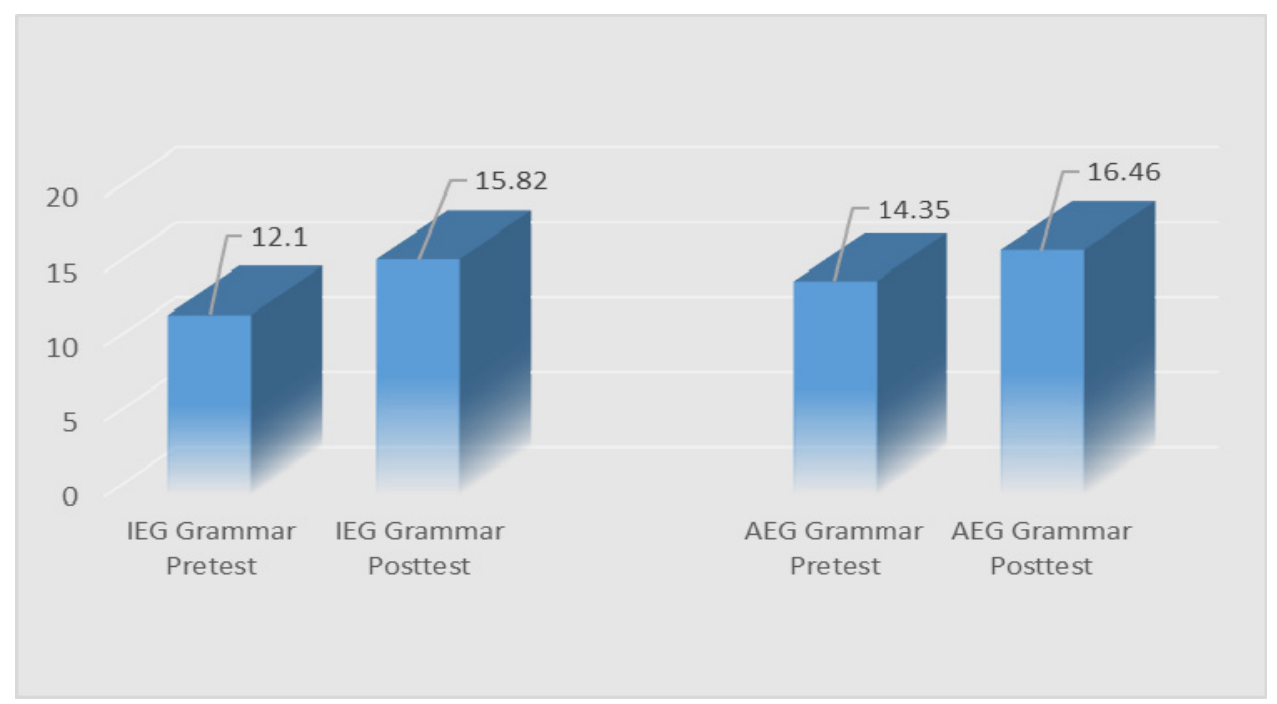

Figure 1. The mean scores of IEG and AEG on the pretest and posttest

It could be clearly seen in Figure 1 that the grammar posttest scores of both IEG and AEG were significantly higher than their pretest scores. The first null hypothesis of the study, thus, was rejected as well.

\subsection{Results for the Second Research Question}

In order to answer the second research question of the study (Does proactive intensive FFI affect the grammatical knowledge of Iranian EFL learners at different proficiency levels equally?), the researchers compared the grammar posttest scores of IEG and AEG through conducting one-way ANCOVA, which controls for the any possible differences between the two groups on their pretest scores, and adjusts their posttest mean scores accordingly. This makes the grammar posttest mean scores of the IEG and AEG comparable. Table 3 shows the descriptive statistics for the related analysis and Table 4 presents the results of one-way ANCOVA for comparing IEG and AEG grammar posttest scores.

Table 3. Descriptive statistics for comparing the posttest scores of the IEG and AEG

\begin{tabular}{llll}
\hline & $N$ & Mean & Std. Deviation \\
\hline IEG & 29 & 15.82 & 1.77 \\
AEG & 28 & 16.46 & 1.64 \\
\hline
\end{tabular}

It could be seen in Table 3 that the grammar posttest mean score of the IEG $(M=15.82)$ was less than the grammar posttest mean score of the AEG $(M=16.46)$. To figure out whether this difference was of statistical significance or not, one needs to cast a look down the Sig. (2-tailed) column across the row in which Proficiency Level (PL) is placed in the ANCOVA table (Table 4) below.

Table 4. Results of one-way ANCOVA for comparing posttest scores of the IEG and AEG

\begin{tabular}{lllllll}
\hline Source & Type III Sum of Squares & $d f$ & Mean Square & $F$ & Sig. & Partial Eta Squared \\
\hline Corrected Model & 151.14 & 3 & 50.37 & 169.36 & .000 & .906 \\
Intercept & 17.67 & 1 & 17.67 & 59.42 & .000 & .529 \\
PL & 1.39 & 1 & 1.39 & 4.68 & .035 & .081 \\
Pretest & 141.91 & 1 & 141.91 & 477.16 & .000 & .900 \\
PL*Pretest & .271 & 1 & .271 & .91 & .345 & .017 \\
Error & 15.76 & 53 & .297 & & & \\
Total & 15016.00 & 57 & & & & \\
Corrected Total & 166.87 & 56 & & & & \\
\hline
\end{tabular}


Under the Sig. column in Table 4.8, the $p$ value corresponding to PL was smaller than the specified alpha level $(.035<.05)$, which means that proficiency level did affect the grammar posttest scores of the IEG and AEG. Under Partial Eta Squared, the relevant value was .081, which indicates that proficiency level accounted for nearly $8 \%$ of the variance in the grammar posttest scores of the IEG and AEG. In addition, the influence of the covariate (i.e. the pretest) is shown in Table 4, the $p$ value for which is .000 . This means that the covariate was also significant in this analysis. In fact, it explained $90 \%$ of the variance in the vocabulary posttest scores of the learners. Last but still important, the Sig. value in front of PL*Pretest was greater than the significance level (i.e. $.345>.05$ ), indicating that the interaction between the covariate and the proficiency level of the learners could not affect their grammar posttest scores significantly. It could thus be concluded that there was a statistically significant difference between IEG and AEG learners with regard to their grammar posttest scores. To put it differently, proactive intensive FFI was more beneficial to intermediate EFL learners' grammatical knowledge than it was to advanced learners' since the average gain score (which could be calculated by subtracting the pretest scores from the posttest scores) of the IEG (3.71) was greater than the average gain score of the AEG (2.11). Consequently, the second null hypothesis of the study was rejected.

\subsection{Results for the Third Research Question}

Finally, the third research question of the study was formulated to investigate whether input delivery method (i.e. with or without FFI) and level of proficiency influenced Iranian EFL Learners' grammatical knowledge, and to find out if there was an interaction effect for FFI and proficiency level in this regard. A two-way ANOVA was conducted for this purpose. The results of this analysis are displayed in Table 5. and 6.

Table 5. Descriptive statistics for comparing FFI vs. no-FFI groups' grammatical knowledge at intermediate and advanced levels

\begin{tabular}{lllll}
\hline Proficiency Level & Groups & Mean & Std. Deviation & $N$ \\
\hline Intermediate & EG & 15.82 & 1.77 & 29 \\
& CG & 13.30 & 1.97 & 26 \\
& Total & 14.63 & 2.24 & 55 \\
\hline Advanced & EG & 16.46 & 1.64 & 28 \\
& CG & 15.66 & 1.27 & 27 \\
& Total & 16.07 & 1.51 & 55 \\
\hline Total & EG & 16.14 & 1.72 & 57 \\
& CG & 14.50 & 2.02 & 53 \\
& Total & 15.35 & 2.03 & 110 \\
\hline
\end{tabular}

Table 5. shows that for both intermediate and advanced levels, the experimental groups gained higher mean scores than the control groups, and that the total mean score of advanced learners $(M=16.07)$ was greater than that of intermediate learners $(M=14.63)$. In order to understand whether the differences between EG and CG at each level, and the differences originating from proficiency levels were statistically significant or not, one has to examine the $p$ values under the Sig. column in Table 6.

Table 6. Results of two-way ANOVA for comparing FFI vs. no-FFI groups' grammatical knowledge at intermediate and advanced levels

\begin{tabular}{|c|c|c|c|c|c|c|}
\hline Source & Type III Sum of Squares & $d f$ & Mean Square & $F$ & Sig. & Partial Eta Squared \\
\hline \multirow{9}{*}{$\begin{array}{l}\text { Corrected Model } \\
\text { Intercept } \\
\text { PL } \\
\text { Groups } \\
\text { PL*Groups } \\
\text { Error } \\
\text { Total } \\
\text { Corrected Total }\end{array}$} & 152.53 & \multirow{9}{*}{$\begin{array}{l}3 \\
1 \\
1 \\
1 \\
1 \\
106 \\
110 \\
109\end{array}$} & 50.84 & 17.92 & .000 & .337 \\
\hline & 25762.96 & & 25762.96 & 9083.51 & .000 & .988 \\
\hline & & & & \multirow{6}{*}{$\begin{array}{l}21.71 \\
26.63 \\
7.17\end{array}$} & .000 & .170 \\
\hline & 61.59 & & 61.59 & & .000 & .201 \\
\hline & 75.54 & & 75.54 & & .009 & .063 \\
\hline & 20.35 & & 20.35 & & & \\
\hline & 300.64 & & 283 & & & \\
\hline & 26387.00 & & & & & \\
\hline & 453.17 & & & & & \\
\hline
\end{tabular}


If you read across PL and reach the value under the Sig. column, you can find that the $p$ value is lower than the significance level (i.e. $.000<.05$ ), indicating that intensive proactive FFI had different effects on the grammatical knowledge of the learners at the two proficiency levels. Furthermore, the $p$ value corresponding to Groups was smaller than the significance level (i.e. .000<.05), which gives rise to the conclusion that EG learners significantly outperformed CG learners. Last but not least, the $p$ value in front of PL*Groups, was less than the alpha level $(.009<.05)$, which means that the interaction of the two independent variables of proficiency level and input delivery method (i.e. with or without FFI) had a significant impact on the learners' grammatical knowledge.

\section{Discussion}

The first research question was whether the grammatical knowledge of Iranian EFL learners at different proficiency levels improved significantly after experiencing proactive intensive FFI. The results obtained for this research question showed that for both intermediate and advanced group learners, the grammatical knowledge of the learners ameliorated significantly in the wake of exposure to proactive intensive FFI. Since a good number of researchers (Allen, 2000; Chen, 2013; Erlam, 2003; Han, 2012; Loewen, 2005; Mellow, 1996) have illustrated the fact that FFI could be conducive to the development of grammatical knowledge of L2 learners, it comes as no surprise that the participants in the current study could take full advantage of the instruction they were exposed to and managed to cultivate their knowledge of English structure. The results of the present study are thus congruent with those of previous studies referred to above.

The second research question investigated whether proactive intensive FFI affected the grammatical knowledge of Iranian EFL learners at different proficiency levels equally or not. The results indicated proactive intensive FFI was more advantageous to intermediate EFL learners' grammatical knowledge than it was to advanced learners'. This could probably be attributed to the fact that advanced learners had already mastered the basic structures of language and hence had little to learn. In other words, ceiling effect might have been at work. That is learners at this level are simply rubbed of the opportunity to absorb a great proportion of L2. Not unlike the results discussed for the first research question, the obtain results for this question is harbinger of the effectiveness of FFI, and thus lending further weight to studies by (Chan, 2006; Izumi, 2002). One study which dealt specifically with the effect of FFI on the knowledge of EFL learners at varying proficiency levels is the one conducted by Salimi, Bonyadi, and Asghari (2014), which showed that high proficiency learners benefited more from FFI than did low proficiency learners. The results of the present study are not diametrically opposed to Salimi, et al. since, as Iwashita (2003) suggested, in order for learners to take in the L2 structures, they need to reach a threshold level. Chances are that the low proficiency learners in Salimi et al.'s study had failed to cross the required threshold level, yet the intermediate learners of the current study might have exceeded the needful threshold.

The third research question was an attempt to scrutinize whether input delivery method and level of proficiency affected Iranian EFL Learners' grammatical knowledge, and to further explore if there was an interaction effect for FFI and proficiency level in this respect. The results revealed that EG learners significantly outscored CG learners, that FFI exerted different degrees of influence on the grammatical competence of the learners at different proficiency levels, and that the interaction of the two independent variables of proficiency level and input delivery method had a significant impact on the learners' grammatical knowledge. As pointed out in the foregoing discussion, the results of the present study corroborated the findings of scholars such as Allen (2000), Chen (2013) Erlam (2003), Han (2012), Izumi (2002), Loewen (2005), and Mellow (1996) by indicating that input delivery method (i.e. with and without FFI) did influence the grammatical knowledge of L2 learners. In addition, not unlike Salimi et al.'s (2013) findings, learners at different proficiency levels were shown to take advantage of FFI not to the same extent. Finally, almost none of the previous studies, to the best of the present researchers' knowledge, addressed the putative interaction effect of FFI and proficiency level on the development of grammatical knowledge of Iranian EFL learners.

The findings of the present study bear some implications for second language acquisition researchers, language practitioners, material developers, and syllabus designers. With regard to SLA, the findings of the study can deepen the insight into effectiveness of FFI for the purpose of grammatical development. As to language practitioners, the findings of the present study are prone to pave the way to choose the best putitaive pedagogical options. syllabus designers and material developers can also benefit from the findinds of this study by incorporating the principles of FFI into their instructional materials designed for particular levels of proficiency.

\section{References}

Allen, L. Q. (2000). Form-meaning connections and the French causative: An experiment in processing 
instruction. Studies in Second Language Acquisition, 22, 69-84. http://dx.doi.org/10.1017/s0272263100001030

Azar, B. (2011). Fundamentals of English grammar (4th ed.). New York, NY: Longman.

Benati, A. (2005). The effects of processing instruction, traditional instruction and meaning-output instruction on the acquisition of the English past simple tense. Language Teaching Research, 9(1), 67-93. http://dx.doi.org/10.1191/13621688051r154oa

Cadierno, T. (1995). Formal instruction from a processing perspective: An investigation into the Spanish past tense. Modern Language Journal, 79(2), 179-193. http://dx.doi.org/10.1111/j.1540-4781.1995.tb05430.x

Chan, S. P. (2006). Qualitative differences in novice teachers' enactment of task-based language teaching in Hong Kong primary classrooms. Unpublished doctoral dissertation, University of Hong Kong.

Chen, J. Y. (2013). Effect of FFI Models on Chinese L2 Accuracy. Master's thesis, The University of Oregon.

DeKeyser R, Salaberry, R., Robinson, P., \& Harrington, M. (2002). What gets processed in processing instruction? A commentary on Bill VanPatten's processing instruction: An update. Language Learning, 52, 480-583. http://dx.doi.org/10.1111/1467-9922.00204

Doughty, C., \& Williams, J. (Eds.). (1998). Focus on form in classroom second language acquisition. Cambridge, UK: Cambridge University Press.

Ellis, R. (2001). Investigating form - focused instruction. Language Learning, 51(1), 1-46. http://dx.doi.org/10.1111/j.1467-1770.2001.tb00013.x

Erlam, R. (2003). Evaluating the relative effectiveness of structured-input and output-based instruction in foreign language learning: Results from an experimental study. Studies in Second Language Acquisition, 25, 559-582. http://dx.doi.org/10.1017/s027226310300024x

Fotos, S. (1994). Integrating grammar instruction and communicative language use through grammar consciousness-raising tasks. TESOL Quarterly, 28(2), 323-351. http://dx.doi.org/10.2307/3587436

Iwashita, N. (2003). Negative feedback and positive evidence in task-based interaction: Differential effects on SL development. Studies in Second Language Acquisition, 25, 1-36. http://dx.doi.org/10.1017/s0272263103000019

Izumi, S. (2002). Output, input enhancement, and the noticing hypothesis. Studies in Second Language Acquisition, 24(4), 541-577. http://dx.doi.org/10.1017/S0272263102004023

Lee, S. K. (2007). Effects of textual enhancement and topic familiarity on Korean EFL students' reading comprehension and learning of passive form. Language Learning, 57(1), 87-118. http://dx.doi.org/10.1111/j.1467-9922.2007.00400.x

Leeman, J., Arteagoitia, I., Fridman, B., \& Doughty, C. (1995). Integrating attention to form with meaning: Focus on form in content based Spanish instruction. In R. Schmidt (Ed.), Attention and awareness in foreign language learning (pp. 259-302). Honolulu: University of Hawaii Press.

Loewen, S. (2005). Incidental focus on form and second language learning. Studies in Second Language Acquisition, 27(3), 361. http://dx.doi.org/10.1017/S0272263105050163

Long, M. (1991). Focus on form: A design feature in language teaching methodology. In K. de Bot, R. Ginsberg, \& C. Kramsch (Eds.), Foreign Language research in cross-cultural perspective (pp. 39-52) Amsterdam: John Benjamins. http://dx.doi.org/10.1075/sibil.2.07lon

Lyster, R. (2007). Learning and teaching languages through content: A counterbalanced approach. Philadelphia: John Benjamins. http://dx.doi.org/10.1075/11lt.18

Mellow, J. D. (1996). A longitudinal study of the effects of instruction on the development of article use by adult Japanese ESL learners. Doctoral dissertation, University of British Columbia.

Norris, J. M., \& Ortega, L. (2000). Effectiveness of L2 instruction: A research synthesis and quantitative meta analysis. Language Learning, 50(3), 417-528. http://dx.doi.org/10.1111/0023-8333.00136

Qin, J. (2008). The effect of processing instruction and dictogloss tasks on acquisition of the English passive voice. Language Teaching Research, 12(1), 61-82. http://dx.doi.org/10.1177/1362168807084494

Radwan, A. A. (2005). The effectiveness of explicit attention to form in language learning. System, 33(1), 69-87. http://dx.doi.org/10.1016/j.system.2004.06.007 
Salimi, A., Bonyadi, A., \& Asghari, A. (2014). The effect of focus on form on EFL learners' written task accuracy across different proficiency levels. Theory and Practice in Language Studies, 4(4), 829-838. http://dx.doi.org/10.4304/tpls.4.4.829-838

Schmidt, R. W. (1990). The role of consciousness in second language learning. Applied Linguistics, 11(2), 129-158. http://dx.doi.org/10.1093/applin/11.2.129

Sharwood-Smith, M. (1981). Consciousness-raising and the second language learner. Applied Linguistics, 2, 159-168. http://dx.doi.org/10.1093/applin/II.2.159

Spada, N. (1997). Form-focused instruction and second language acquisition: A review of classroom and laboratory research. Language Teaching, 30(02), 73-87. http://dx.doi.org/10.1017/S0261444800012799

Spada, N., Lightbown, P. M., \& White, J. L. (2005). The importance of form/meaning mappings in explicit form-focused instruction. In A. Housen, \& M. Pierrard (Eds.). Current issues in instructed second language learning (pp. 199-234), Berlin: Mouton de Gruyter. http://dx.doi.org/10.1515/9783110197372.2.199

Swain, M. (2000). French immersion research in Canada: Recent contributions to SLA and applied linguistics. Annual Review of Applied Linguistics, 20, 199-212. http://dx.doi.org/10.1017/S0267190500200123

VanPatten, B. (1996). Input processing and grammar instruction: Theory and research. Norwood, NJ: Ablex.

VanPatten, B. (2000). Processing instruction as form-meaning connections: Issues in theory and research. In J. F. Lee, \& A. Valdman (Eds.), Form and meaning: Multiple perspectives (pp. 43-68). Boston: Heinle \& Heinle.

White, J. (1998). Getting the learners' attention: A typographical input enhancement study. In C. Doughty, \& J. Williams (Eds.), Focus on form in classroom second language acquisition (pp. 85-113). New York: Cambridge University Press.

White, J., \& Ranta, L. (2002). Examining the interface between metalinguistic task performance and oral production in a second language. Language Awareness, 11(4), 259-290. http://dx.doi.org/10.1080/09658410208667060

Williams, J. N. (2005). Learning without awareness. Studies in Second Language Acquisition, 27(2), 269-304. http://dx.doi.org/10.1017/S0272263105050138

\section{Copyrights}

Copyright for this article is retained by the author(s), with first publication rights granted to the journal.

This is an open-access article distributed under the terms and conditions of the Creative Commons Attribution license (http://creativecommons.org/licenses/by/3.0/). 